\title{
PERANCANGAN KENDALI PID DENGAN MODEL PROCESS REACTION CURVE PADA SHOWCASE JAMUR MERANG
}

\author{
Karsid ${ }^{1}$, Rofan Aziz ${ }^{2}$ \\ ${ }^{1,2}$ Jurusan Teknik Pendingin dan Tata Udara, Politeknik Negeri Indramayu \\ Jl.Raya Lohbener Lama No.08 Lohbener-Indramayu 45252 \\ Email: karsids@yahoo.co.uk \\ Email: sambalewa_live@yahoo.com
}

\begin{abstract}
ABSTRAK
Jurnal ini menyajikan sebuah model empiris untuk mensimulasikan karakteristik sistem pendingin untuk jamur merang. Model matematika didasarkan pada hasil pengukuran suhu. Parameter, seperti, Gain $(\mathrm{K})$, waktu tunda $(\theta)$, dan waktu konstan $(\tau)$ diperoleh dari nilai-nilai eksperimental. Sistem pendingin dirancang dengan menggunakan metode kurva reaksi proses, sedangkan pengontrol PID dengan metode korelasi Ciancone. Kontrol PID berhasil diterapkan, hal ini dapat dilihat dari tidak adanya kesalahan tunak, respon sistem yang lebih cepat mencapai set-point, overshoot dan undershoot tidak terlalu jauh dari nilai masukan.
\end{abstract}

Kata Kunci : Sistem Pendingin; Jamur Merang; Kurva Reaksi Proses; Pengontrol PID;

\begin{abstract}
The present work proposes a empirical model to simulate the steady-state behavior of a refrigeration sistem for paddystraw mushroom (showcase). The current mathematical model is based on result of measurement temperature. Parameters, such as, Gain $(\mathrm{K})$, delay time $(\theta)$, and time constant $(\tau)$ are obtained from experimental values.The sistem designed using the process reaction curve method, while the PID controller with correlation method Ciancone. PID control successfully implemented, it can be seen from the absence of steady-state error, a faster sistem response reach the set-point, overshoot and undershoot is not too far from the input value.
\end{abstract}

Keywords : Refrigeration Sistem; Paddystraw Mushroom; Process Reaction Curve; PID Controller;

\section{PENDAHULUAN}

Jamur merang merupakan produk pertanian yang mudah rusak dan tidak dapat disimpan dalam jangka waktu yang lama pada kondisi suhu kamar normal. Bahkan, menurut Etty Sumiati dan Diny Djuariah, Jamur merang mempunyai umur simpan kurang dari satu hari atau maksimum satu hari. Menurut Tao (1), Untuk memperpanjang umur simpan jamur dapat dilakukan dengan 3 cara pengkondisian, yaitu disimpan pada ruang dingin dengan suhu $4 \pm 1^{\circ} \mathrm{C}$ dengan $\mathrm{RH} 75 \%$. Maka diperlukan control terhadap suhu dan kelembaban udara pada ruang penyimpan jamur merang tersebut. Dewasa ini sistem control yang diterapkan pada sistem refrigerasi masih menggunakan sistem control posisi $O N-O F F$. Untuk mendapatkan tanggapan sistem yamg lebih presisi diperlukan kendali PID.

Pada aplikasi industri sistem-sistem saling berhubungan satu dengan yang lainnya.Seperti yang terdapat pada: petro-kimia, pembuatan kertas dan instalasi pengolahan air. Banyak dari aplikasi ini menyebabkan proses pengendalian mengalami 
kesulitan, seperti penundaan waktu, interaksi multivariabel dan dinamika non minimum fase (2). Pengukuran dan pengukuran control seperti temperature, tekanan, laju aliran, $\mathrm{pH}$, kelembaban, level adalah penting pada proses industri. Dimana tanggapan dari sistem atau proses diidentifikasi sebagai model dan di validasi, model digunakan untuk penalaan kendali (3).

Proses yang mempunyai satu keluaran dapat dikontrol menggunakan manipulasi varibel tunggal. Kontrol seperti ini dinamakan single input-single output (SISO). Pada industri proses tidak hanya memiliki satu kalang kontrol. Pada faktanya pada banyak aplikasi memerlukan kontrol paling sedikit dua variabel. Sistem dengan yang memiliki kalang kontrol lebih dari satu disebut multi input multi output (MIMO) atau sistem multivariabel (4). Uji eksperimental secara empirik digunakan untuk mengevaluasi performansi sistem refrigerasi domestik dimana berhubungan pengontrolan suhu dan kelembaban pada kabin. Perancangan sistem refrigerasi biasanya didasarkan pada pengalaman pendahulu. Beberapa pengujian digunakan untuk mengetahui performansi dan digunakan untuk optimasi sistem (5). Pengendali PID diaplikasikan pada banyak pengendalian sistem. Akan tetapi beberapa menunjukan kekurangan disebabkan oleh ketidaklinieran dan adanya ketidakpastian (6). Model yang didasarkan pada data empirik ini digunakan untuk mengontrol temperatur dari sistem showcase penyimpan jamur merang.

\section{METODE PENELITIAN}

Proses penelitian dapat dilihat pada gambar 1. Dimulai dengan studi literatur, dimana pada aplikasi kontrol sistem pendingin masih menggunakan kontrol posisi (ON-OFF). Karakteristik tanggapan sistem dari kontrol posisi $(O N-O F F)$ dapat dilihat pada gambar 2. Dari gambar tersebut dapat dilihat bahwa masih ada perbedaan nilai yang diinginkan dengan keluaran yang dihasilkan. Untuk mengatasi hal tersebut maka penulis mendesain kontrol PID. Kemudian diambil data empirik sistem pendinginan pada showcase pengawetan jamur merang untuk dilakukan pemodelan sistem. Adapun struktur model Process Reaction Curve (PRC) adalah :

$$
G_{s}=\frac{K e^{-\theta s}}{\tau s+1}
$$

Dimana : $\mathrm{G}_{\mathrm{s}}$ adalah sistem

K adalah Penguatan (Gain)

$\theta$ adalah waktu tunda

$\tau$ adalah time constat

Estimasi parameter model yaitu $\left(\mathrm{K}_{\mathrm{p}}, \theta, \tau\right)$ dilakukan dari grafik yang yang diplot dari pengambilan data sistem secara emprik. Setelah didapatkan model dilakukan evaluasi dan diagnosis apakah model sudah mewakili sistem sebenarnya apa belum. Model diverifikasai apabila telah mewakili sistem sebenarnya. 


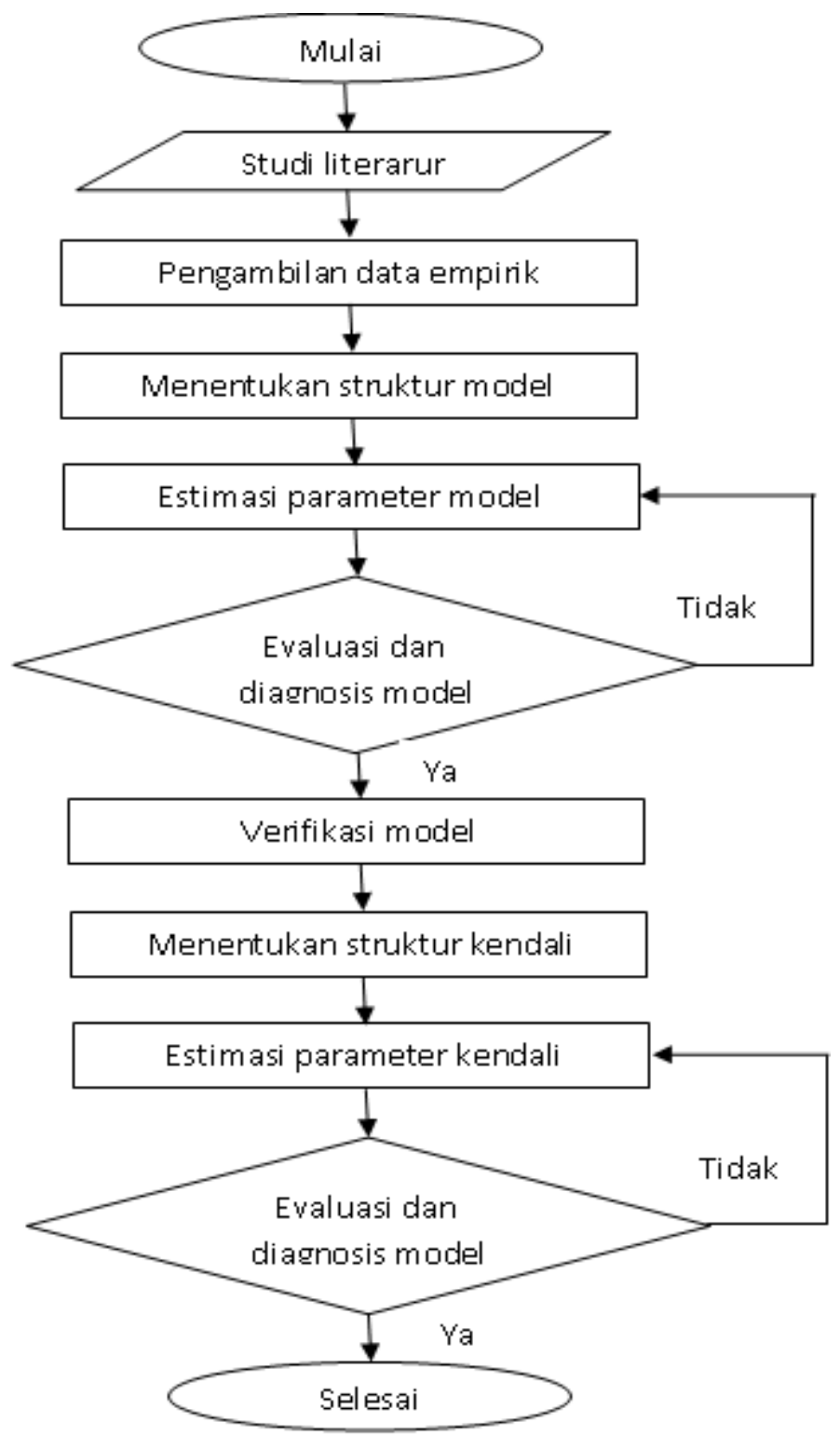

Gambar 1. Diagram Alir Proses Penelitian

Temperature (C) $\quad$ Humidity (\%)

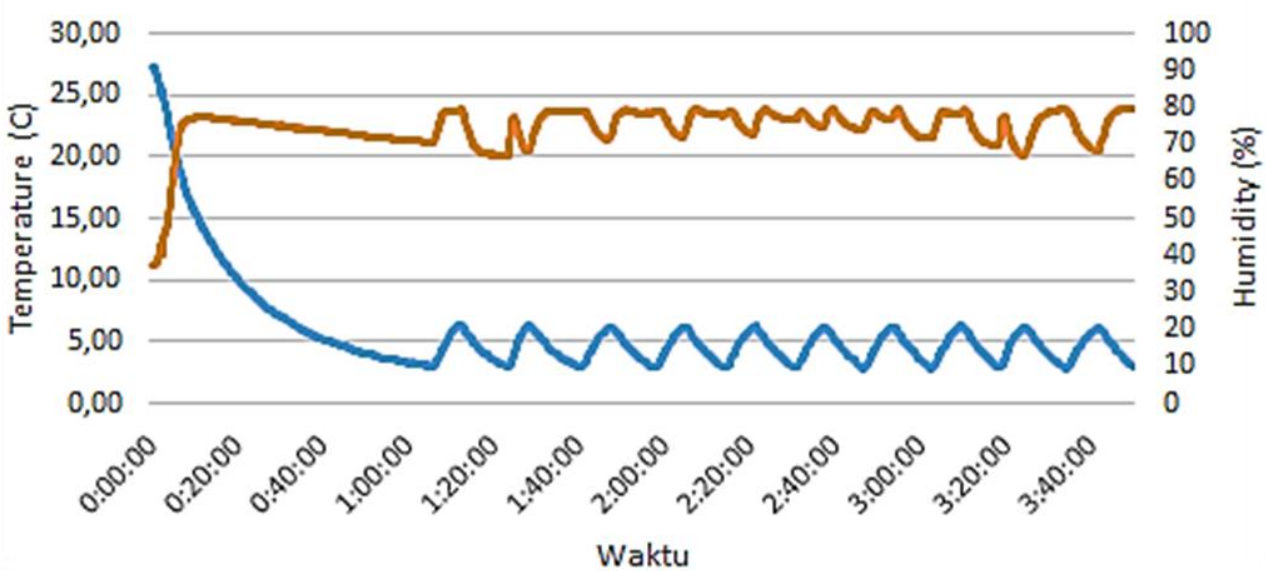

Gambar 2. Grafik Performansi Kontrol Digital

(Sumber : Rofan Aziz, Karsid (7)) 


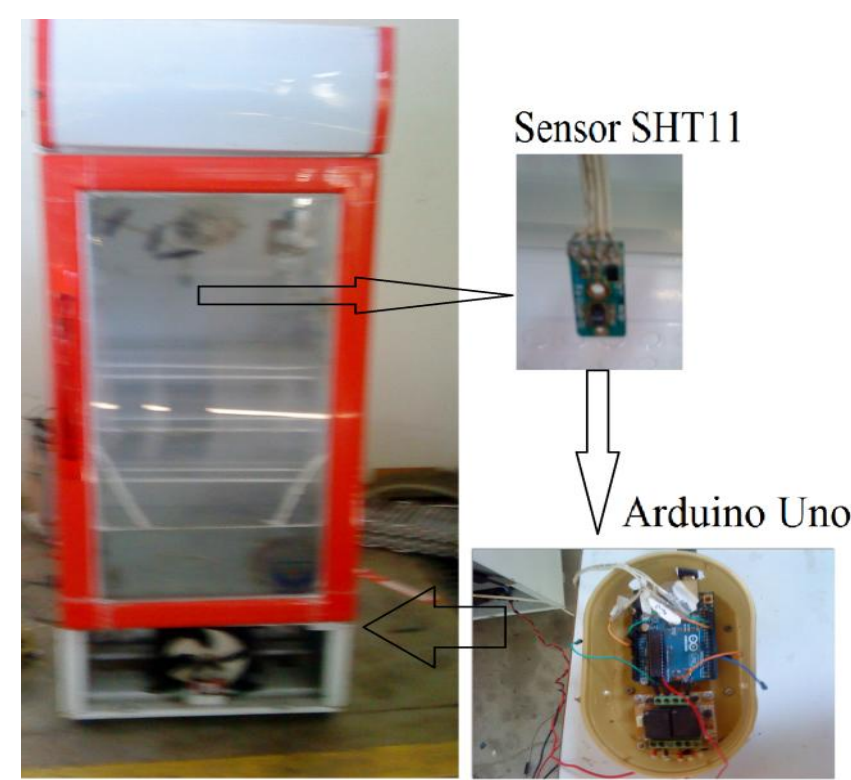

Showcase

Gambar 3. Sistem Showcase Jamur Merang

Spesifikasi showcase yang digunakan adalah :

Tabel 1. Spesifikasi showcase

\begin{tabular}{ll}
\hline Ukuran $(\mathrm{p} \times 1 \times \mathrm{t})$ & $560 \times 495 \times 1530 \mathrm{~mm}$ \\
\hline Kapasitas & 150 liter \\
Tegangan & $220 \mathrm{~V} / 50 \mathrm{~Hz}$ \\
Arus Listrik & $0,9 \mathrm{~A}$ \\
Gas Pendingin & $\mathrm{R}-134 \mathrm{~A}$ \\
Daya Listrik & $115 \mathrm{~W}$ \\
Berat Bersih & $38 \mathrm{Kg}$ \\
\hline
\end{tabular}

Pengambilan data dilakukan dengan menggunakan modul ARDUINO UNO, dimana data ditampilkan pada program Microsoft Excel, data di cuplik per 20 detik sampai sistem tunak. Hasil pengambilan data dapat dilihat pada gambar 4. Dimana sistem masih ada nilai kesalahan antara nilai temperatur yang diinginkan dengan keluaran sistem.

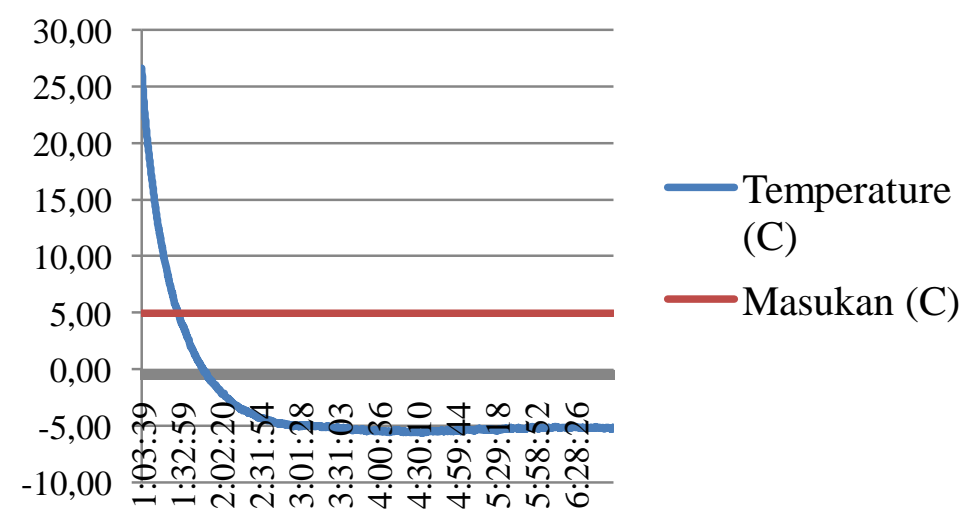

Gambar 4. Grafik nilai temperatur

Perancangan kendali berdasarkan model yang telah didapatkan tadi dilakukan dengan menentukan struktur kendali, estimasi parameter kendali, evaluasi dan diagnosis terhadap 
hasil pengendalian terhadap sistem, apakah pengendalian telah berhasil dilakukan atau belum. Adapaun struktur kendali PID adalah :

$$
U(t)=K_{c} e(t)+1 / \tau_{i} \int_{0}^{t} e(t) d t-\tau_{d} \frac{d e(t)}{d t} .
$$

Sehingga diperoleh fungsi alih pengendali PID sebagai berikut :

$$
\frac{U(s)}{E(s)}=K_{p}+\frac{K_{i}}{s}-K_{d} s
$$

Dimana :

$$
\begin{aligned}
& \mathrm{K}_{\mathrm{p}}=\text { Konstanta penguat proporsional } \\
& \mathrm{K}_{\mathrm{i}}=\text { Konstanta penguat integral } \\
& \mathrm{K}_{\mathrm{d}}=\text { Konstanta penguat derivatif }
\end{aligned}
$$

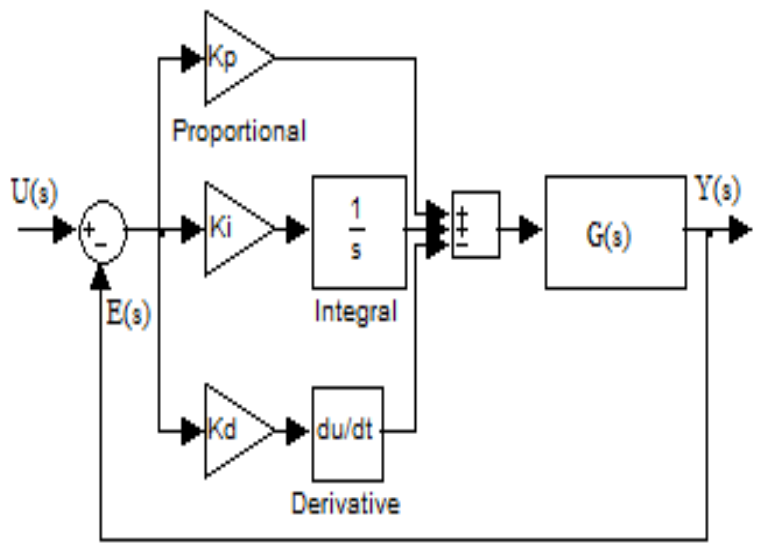

Gambar 5. Diagram blok sistem

\section{HASIL DAN PEMBAHASAN}

Data hasil pengukuran eksperimental kemudian dimasukan pada program matlab untuk dilakukan pemodelan. Hasil pengambilan data suhu dari showcase jamur merang dapat diihat pada grafik dibawah ini :

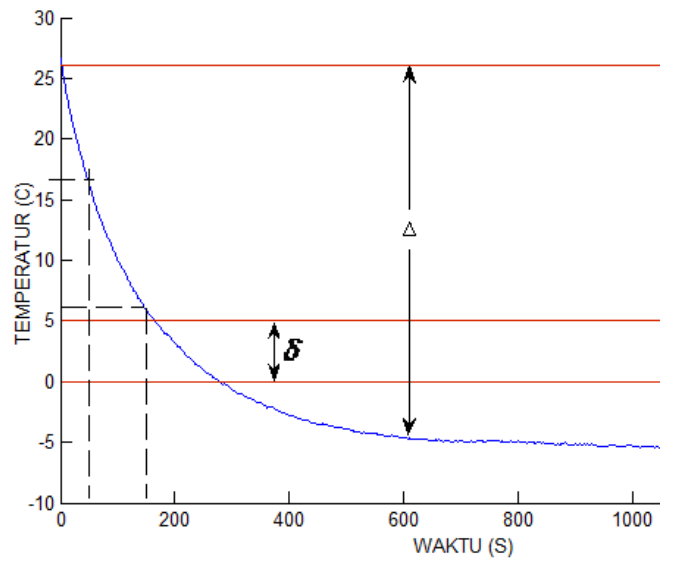

Dimana :

$\Delta$ : Nilai akhir - Nilai awal

$\delta$ : Nilai Masukan

Gambar 6. Proses Pemodelan Eksperimental

Dari gambar diatas didapatkan data-data sebagai berikut :

$$
\begin{aligned}
& \Delta=31.8 \\
& \delta=5 \\
& \mathrm{~K}=\Delta / \delta=\frac{31.8}{5}=6.36
\end{aligned}
$$




$$
\begin{aligned}
& \mathrm{t}_{28 \%}=60 \mathrm{~s} \\
& \mathrm{t}_{63 \%}=160 \mathrm{~s} \\
& \tau=1.5\left(t_{63 \%}-t_{28 \%}\right)=150 \mathrm{~s} \\
& \theta=t_{63 \%}-\tau=10 \mathrm{~s}
\end{aligned}
$$

Jadi fungsi alih sistem showcase jamur merang adalah :

$$
G_{S}=\frac{6.36 e^{-10 s}}{150 s+1}
$$

Kemudian untuk memvalidasi model sistem diatas diperlukan pengujian dengan mensimulasikan sistem tersebut, dimana hasilnya adalah sebagai berikut :
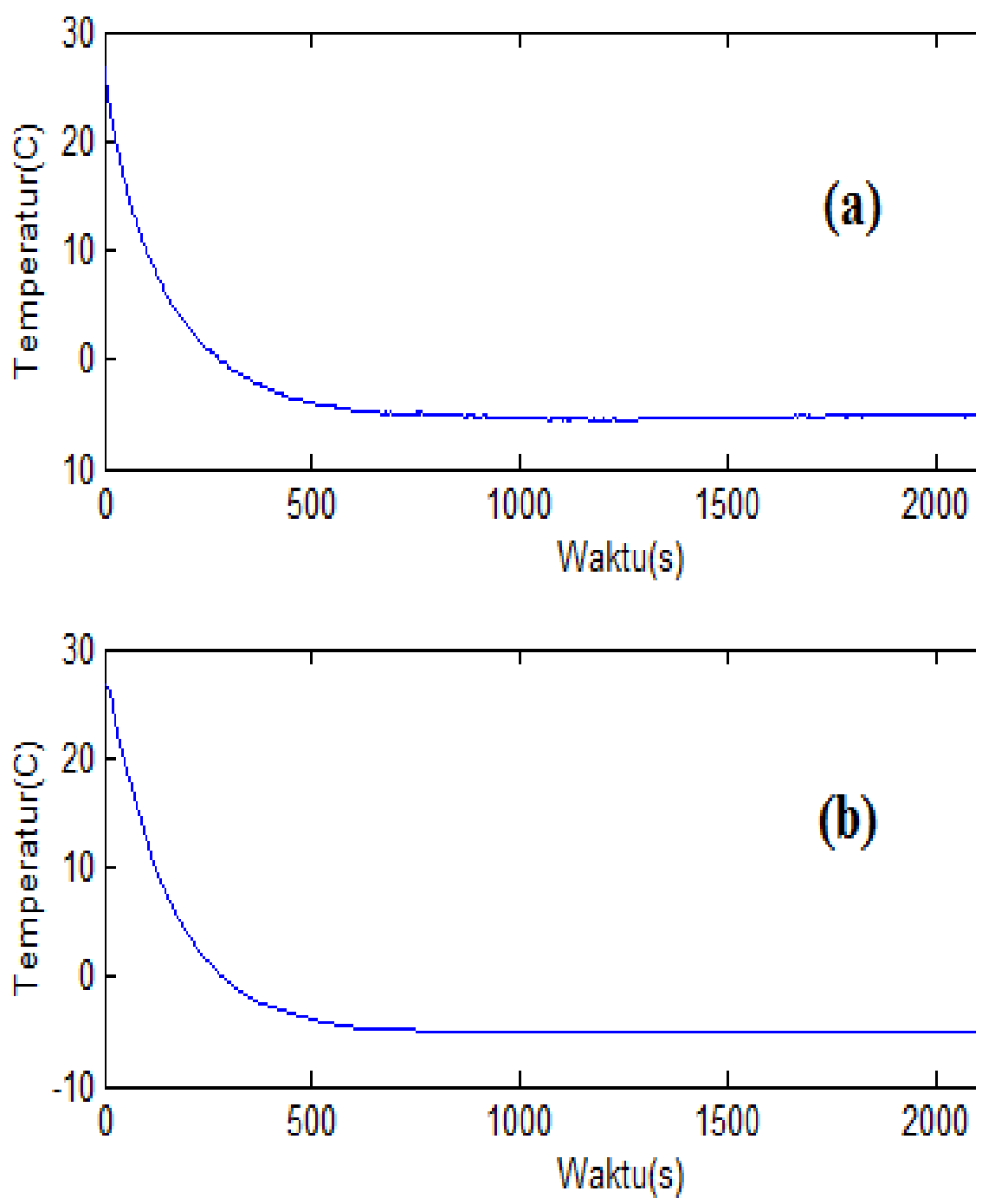

Gambar 7. Tanggapan sistem (a). Sistem Nyata, (b). Hasil Pemodelan PRC

Dari gambar 7 diatas dapat dilihat bahwa tanggapan sistem hasil pemodelan PRC sudah sesuai dengan tanggapan sistem nyata showcase jamur merang. Langkah selanjutnya adalah penyetelan PID, dimana dilakukan dengan menggunakan korelasi Ciancone (8). Konstanta konstanta PID diperoleh secara grafik dengan memasukan nilai-nila $K, \vartheta$ dan $\tau$ yang telah diperoleh dari grafik sistem nyata. Grafik untuk penyetelan PID dengan metode Korelasi Ciancone dapat dilihat pada gambar 8. 


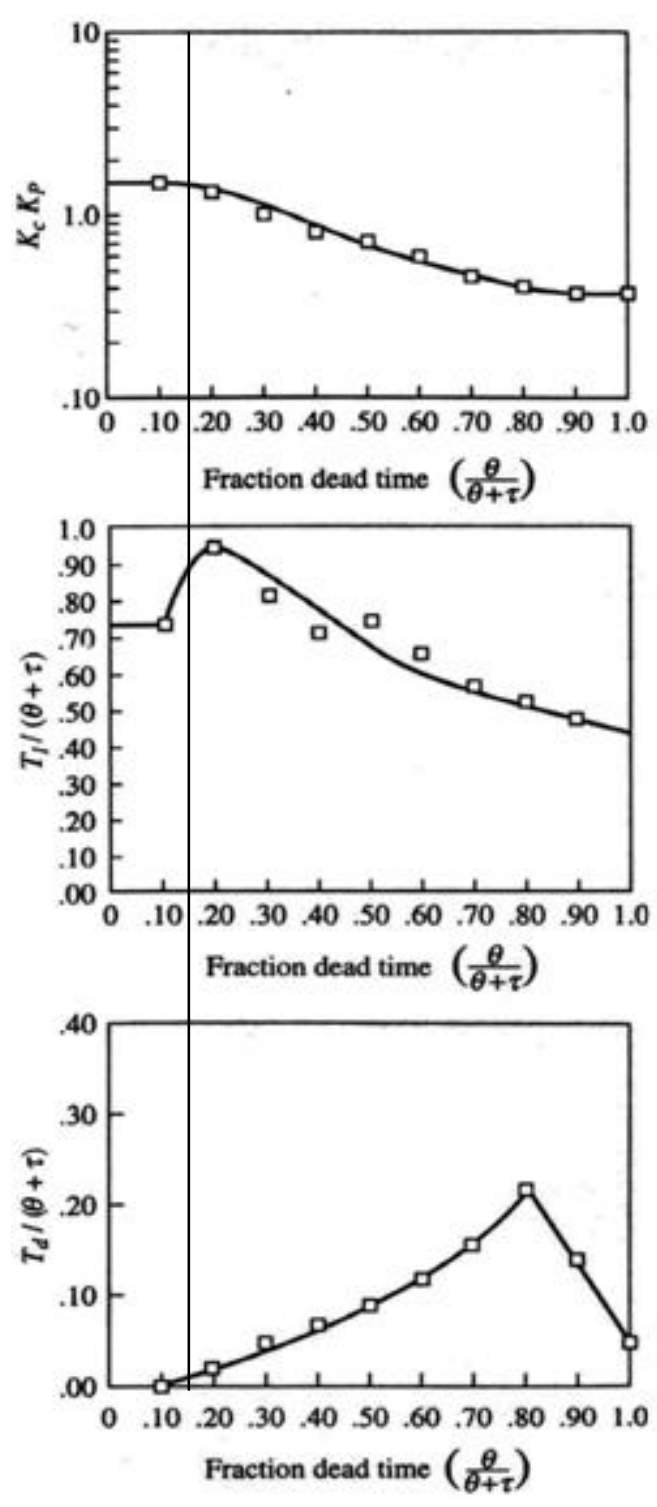

Gambar 8. Grafik Penalaan PID metode Korelasi Ciancone

Dari gambar diatas dapat ditentukan nilai-nilai parameter-parameter PID sebagai berikut :

$$
\begin{aligned}
\vartheta / \vartheta+\tau & =10 /(10+150)=0.0625 \\
K_{c} K_{p} & =2 \\
K_{c} & =2 / K_{p}=2 / 6.36=0.31 \\
\tau_{i} /(\vartheta+\tau) & =0.725 \\
\tau_{i} & =0.725(\vartheta+\tau) \\
& =0.725(10+150)=116 \\
\tau_{d} /(+\tau) & =0 \\
\tau_{d} & =0(\vartheta+\tau)=0 / 160=0
\end{aligned}
$$

Diagram blok sistem beserta pengendali PID yang akan disimulasikan pada program SIMULINK dapat dilihat pada gambar dibawah ini : 


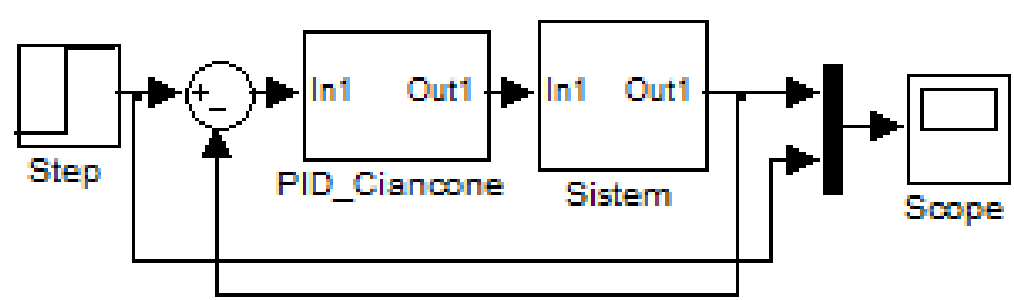

(a)

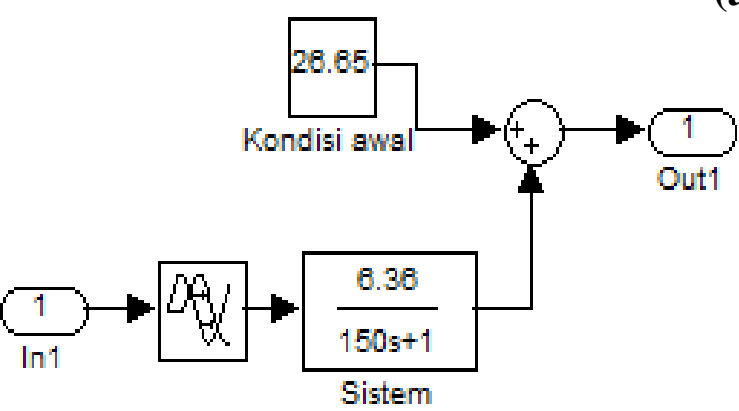

(b)

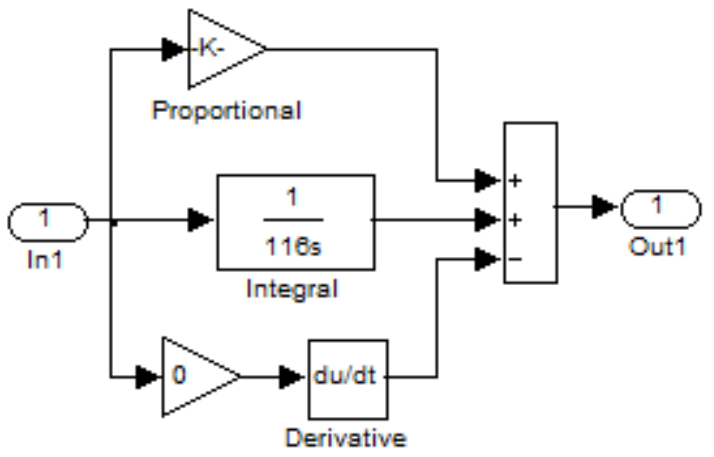

(c)

Gambar 9. Diagram blok sistem (a). Diagram blok sistem beserta kontrol PID, (b).

Diagram blok sistem, (c). Digram blok kontrl PID

Hasil simulasi SIMULINK pada pengendalian PID pada sistem showcase jamur merang dapat dilihat pada gambar dibawah ini :

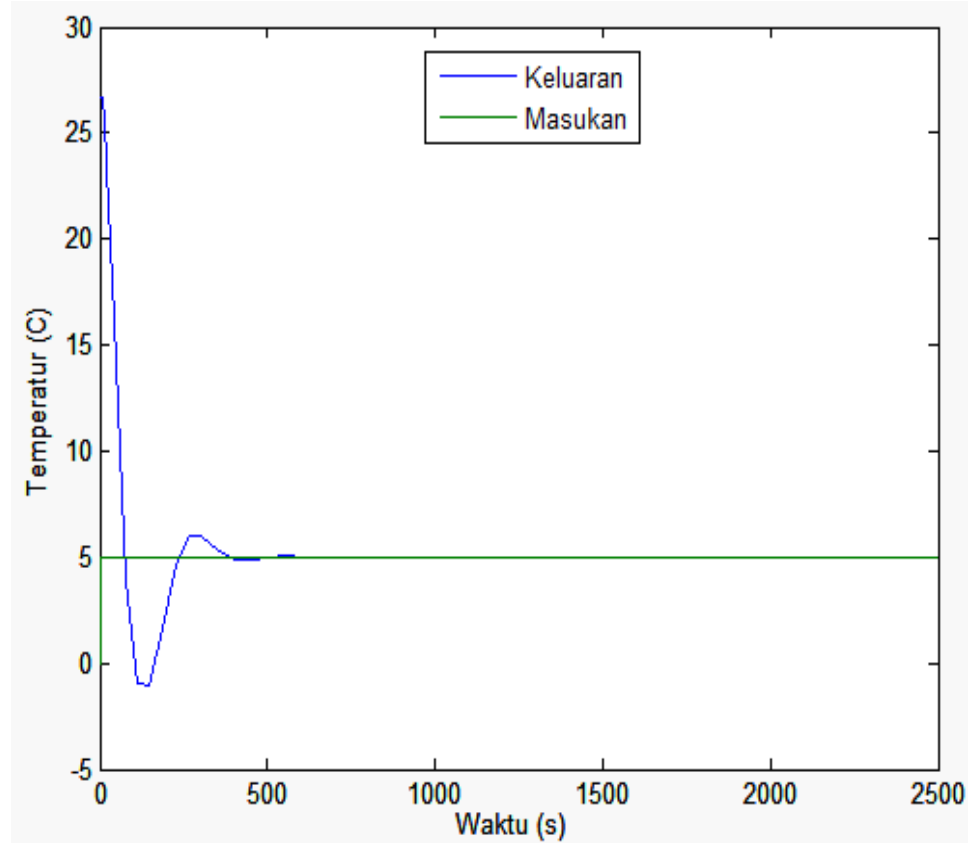

Gambar 10. Grafik simulasi karakteristik sistem hasil penerapan kontrol PID

Dari gambar diatas dapat dilihat bahwa keluaran sistem setelah diterapkan kendali PID dapat mengkompensasi kesalahan tunak sehingga keluaran tunak sistem sama dengan masukan, tanggapan sistem juga lebih cepat mencapai masukan, ini berarti proses pengendalian sistem showcase jamur merang berhasil dilakukan. Ada juga overshoot pada 
keluaran sistem mencapai $-1{ }^{0} \mathrm{C}$. Sedangkan undershoot mencapai $1{ }^{0} \mathrm{C}$ sebelum sistem mencapai kondisi tunak.

\section{KESIMPULAN}

Dari uraian yang telah dijelaskan sebelumnya dan analisa hasil simulasi, maka dapat diambil kesimpulan sebagai berikut :

1. Sistem showcase jamur merang yang dikendalikan merupakan single input-single output (SISO) karena hanya melibatkan satu variable yaitu temperature.

2. Pemodelan sistem dengan metode Process Reaction Curve dapat dilakukan. Hal ini dapat dilihat dari hasil perbandingan pada grafik sistem nyata dan hasil simulasi SIMULINK. Dimana grafik hasil sistem hasil simulasi memiliki kecenderungan keluaran sistem yang sama dengan grafik sistem nyata.

3. Proses pengendalian PID dengan metode Korelasi Ciancone berhasil diterapkan. Hal ini dapat dilihat dari tidak adanya kesalahan tunak, tanggapan sistem lebih cepat mencapai setpoint, overshoot dan undershoot yang tidak terlalu jauh dari nilai masukan sistem.

\section{UCAPAN TERIMA KASIH}

Penulis mengucapkan terima kasih kepada direktur Politeknik Indramayu, Ketua Jurusan Teknik Pendingin dan Tata Udara yang telah memberikan dukungan. Demikian juga Kami ucapkan kepada Kemenristek Dikti yang telah memberikan dukungan dana pada penelitian ini.

\section{DAFTAR PUSTAKA}

1. Tao F, Zhang M, Jincai S. Preservation of mushroom in storage after cooling treatment. Int.Agrophysics. 2005; 19: 293-297.

2. Anca Maxim, Clara M. Ionescu, Cosmin Copot, Robin De Keyser. Multivariable Model-Based Control Strategies for Level Control in a Quadruple Tank, Sistem Theory, Control and Computing (ICSTCC). 17th International Conference IEEE; 2013; p.343348.

3. P. Aravind. S.M. Giriraj Kumar. Application of Optimization Technique to Tune PID Controller for a Level Process. International Journal of Computer Applications. 2014 April; 91(16): p. 0975-8887.

4. Tham M T. Multivariable Control An Introduction to Decoupling Control. Departement of Chemical and Process Engineering University of Newcastle: Upon Tyne; 2009.

5. Cezar O R. Negrão, Raul H Erthal, Cassio A Yared, Diogo da Vinha Andrade. SemiEmpirical Model For Steady State Simulation Of Domestic Refrigeration Sistems. 12th Brazilian Congress of Thermal Engineering and Sciences Copyright (C) 2008 by ABCM November 10-14, 2008, Belo Horizonte, MG, Federal University of Technology , Paraná.

6. N. Nithya Rani, S.M.Giriraj Kumar, N. Anantharaman. Modeling And Control Of Temperature Process Using Genetic Algorithm. International Journal of Advanced 
Research in Electrical, Electronics and Instrumentation Engineering (An ISO 3297:2007 Certified Organization). 2013 November: 2(11)

7. Aziz R, Karsid. Uji Performansi Kontrol Suhu Dan Kelembaban Menggunakan Variasi Kontrol Digital Dan Kontrol Scheduling Untuk Pengawetan Buah Dan Sayuran. Jurnal Nasional Teknik Elektro Universitas Andalas. 2015 September; 4 (2): 215-219

8. Ashok Kumar, Munish Vashishath. Performance Comparison Between Various Tuning Strategies: Ciancone, Cohen Coon \& Ziegler- Nicholas Tuning Methods. International Journal of Computers \& Technology. 2013 May-June; 5(1). 